\title{
CA Repeat
}

National Cancer Institute

\section{Source}

National Cancer Institute. CA Repeat. NCI Thesaurus. Code C45810.

A dinucleotide repeat consisting of (CA/GT)n. 